IZA DP No. 7569

Preferences for Employment Protection and the Insider-Outsider Divide

Elvire Guillaud

Paul Marx

August 2013

Forschungsinstitut zur Zukunft der Arbeit Institute for the Study of Labor 


\title{
Preferences for Employment Protection and the Insider-Outsider Divide
}

\author{
Elvire Guillaud \\ University Paris 1 Pantheon-Sorbonne, CES \\ Paul Marx \\ University of Southern Denmark \\ and IZA
}

Discussion Paper No. 7569

August 2013

IZA
P.O. Box 7240
53072 Bonn
Germany

Phone: +49-228-3894-0

Fax: +49-228-3894-180

E-mail: iza@iza.org

\begin{abstract}
Any opinions expressed here are those of the author(s) and not those of IZA. Research published in this series may include views on policy, but the institute itself takes no institutional policy positions. The IZA research network is committed to the IZA Guiding Principles of Research Integrity.

The Institute for the Study of Labor (IZA) in Bonn is a local and virtual international research center and a place of communication between science, politics and business. IZA is an independent nonprofit organization supported by Deutsche Post Foundation. The center is associated with the University of Bonn and offers a stimulating research environment through its international network, workshops and conferences, data service, project support, research visits and doctoral program. IZA engages in (i) original and internationally competitive research in all fields of labor economics, (ii) development of policy concepts, and (iii) dissemination of research results and concepts to the interested public.
\end{abstract}

IZA Discussion Papers often represent preliminary work and are circulated to encourage discussion. Citation of such a paper should account for its provisional character. A revised version may be available directly from the author. 
IZA Discussion Paper No. 7569

August 2013

\section{ABSTRACT \\ Preferences for Employment Protection and the Insider-Outsider Divide}

Insider-outsider theory suggests that in dual labour markets two groups have opposing preferences regarding protection against dismissals: insiders defend employment protection, because it increases their rents. Outsiders see it as a mobility barrier and demand deregulation. Similar divides are expected for unemployment benefits: as insiders and outsiders have diverging unemployment risks, they should demand different levels of protection. Although these views are influential in the political economy debate, there is little empirical research on the effect of contract types on social and labour market policy preferences. We use a novel data set collected in the most recent presidential contest in France, which combines detailed information on respondents' employment status with questions measuring attitudes towards dismissal regulation and other labour market policies. Going beyond insider-outsider theory, we argue and show empirically that the effect of membership in either segment is moderated by the employment situation in workers' occupation.

JEL Classification: J08, J41, K31

Keywords: employment protection, insider-outsider theory, political preferences, France, single employment contract

Corresponding author:

Paul Marx

University of Southern Denmark

Department of Political Science and Public Management

Campusvej 55

5230 Odense $\mathrm{M}$

Denmark

E-mail:marx@sam.sdu.dk 


\section{Introduction}

Prominent political economy theories deal with the question of what determines individuals' preferences for or against employment protection. It has been suggested that in dual labour markets two groups oppose each other whose interests are irreconcilable: while insiders (those with permanent employment contracts) defend dismissal regulation because it increases their rents, outsiders (the unemployed and temporary workers) see it as a mobility barrier to the primary labour market segment and demand deregulation (Rueda 2005; 2007; Saint-Paul 1996). This theoretically influential argument has so far not been tested directly. The main reason arguably is a lack of suitable data, as survey questions measuring support for employment protection are rare. In this paper, we overcome this problem by using a novel data set collected in the most recent presidential contest in France (Guillaud and Sauger 2013), which combines detailed information on respondents' employment status with questions measuring attitudes towards dismissal regulation and other labour market policies. France is a particularly interesting case, since employment protection has ranked high on the political agenda for decades (Blanchard and Tirole 2003). Moreover, at the time of data collection concrete reform options were discussed in the French media, ensuring that the topic was salient to the voters.

The results disconfirm the theoretical argument that temporary workers demand de-regulation of employment protection. Permanent and temporary workers do not have significantly different preferences on this particular issue. Where they do differ, however, is regarding preferences for generosity of unemployment benefits. Outsiders, including temporary workers, demand more unemployment protection. In sum, the results reaffirm scepticism on political behaviour implications of insider-outsider theory and lend support to recent theorizing on the link between employment risks and welfare state preferences (Cusack et al. 2006; Hacker et al. 2013; Rehm 2009).

Moreover, our results indicate insider-outsider conceptualisation based on employment contract to be too narrow to capture preferences for employment protection (for a related argument see Häusermann and Schwander 2012). Workers formally belonging to the insider segment can be sheltered from unemployment because of the favourable labour demand and supply conditions in their occupations. Going beyond insider-outsider theory, we argue and show empirically that the effect of membership in either segment is moderated by occupational unemployment rates. In 
occupations with low unemployment, permanent workers exhibit lower support for employment protection.

\section{Labour market status and preferences for employment protection}

Employment (or dismissal) protection comprises regulations constraining managerial freedom to fire workers at will (Venn 2009). As such it is an institution beneficial to workers and cherished by trade unions (Botero et al. 2004; Davidsson and Emmenegger 2013). Saint-Paul (1996; 2000) argues, however, that such regulations are not in the interest of the entire working class. Employment protection is beneficial to the employed, because it increases costs of firing them after failed wage negotiations and therefore allows to "artificially create monopoly power" (Saint-Paul 2000: 270) and bidding up wages (see also Lindbeck and Snower 1988; 2001). Moreover, there is a sizeable group of low-productivity workers whose jobs would be destroyed in the absence of employment protection. The losers of employment protection are the unemployed, for whom regulations imply lower job finding rates (since employers are more hesitant to make potentially costly commitments to long-term employment) (Bentolila and Bertola 1990). The argument has been extended to include non-standard workers into the category of outsiders (primarily those on temporary employment contracts) (Bentolila and Dolado 1994; Dolado et al. 2002; Rueda 2005). Also for them dismissal regulation does not serve as a protective institution, but as a mobility barrier into the primary labour market segment. In sum, outsiders' demands for deregulation are “justified by their beliefs that lower employment protection will facilitate their exit from unemployment and precarious employment” (Rueda 2005: 64). From this perspective, we can hypothesise that the (permanently) employed should have a stronger preference for maintaining employment protection than the unemployed and workers on temporary contracts.

The model has been contested on theoretical grounds. Emmenegger (2009) is agnostic about the explanatory power of labour market status for preferences for dismissal regulation, because first, voters are rarely rational or sophisticated enough to make the necessary calculations of institutional effects on their welfare; second, labour market divides run through household units which may blur the conflict over employment protection; and third, prospects of upward mobility may lead outsiders to anticipate and adopt insider preferences. In addition, Emmenegger (2009) 
and Marx (forthcoming) point to open questions in how outsiders in the model translate policy preferences into party support: Saint-Paul (1996) as well as Rueda (2005) argue that next to employment protection, insiders and outsider also diverge on how much to spend on unemployed benefits. Insiders face low unemployment risks and prefer relatively little spending, outsiders face high risks and demand more spending. This squares well with the literature stipulating a positive effect of employment risks on welfare state preferences (Cusack et al. 2006; Guillaud 2013; Iversen and Soskice 2001; Rehm 2009). The problem is that the specific policy mix of deregulating employment protection and increasing unemployment protection can rarely be found in political manifestos. Typically parties are either supportive (the left) or hostile (the right) towards both policies at the same time. This implies that outsiders have to prioritize between their assumed preference for employment protection deregulation and unemployment protection expansion. The insider-outsider model does not provide a theoretical prediction which issue will dominate in voters' decision making.

Empirically, to our knowledge the claim of lower support for employment protection among outsiders has not been addressed directly. Tentative support comes from Dolado et al. (2002) as well as Bentolila et al. (2012) who show for Spain that deregulation of employment protection has occurred in times in which outsiders outnumber insiders. Micro level evidence is limited. Using two ISSP questions (government support for declining industries and personal importance of job security) Emmenegger (2009) shows that atypical workers indeed show less support for employment protection compared to insiders. The unemployed, however, are equally supportive as insiders. Marx (forthcoming) does not find any positive effect of temporary contracts (vs. permanent ones) on support for conservative or liberal parties, which are the most likely party families to deregulate labour markets. However, his finding of a positive effect on support for Green parties could indicate that temporary workers prefer left parties with less historical commitment to employment protection than it is characteristic for Social Democracy. In any case, one should bear in mind that party support as well as the items used by Emmenegger (2009) are not more than crude proxies for support of employment protection. Evidence on outsiders' higher demand for unemployment protection has been provided by Boeri et al. (2001), Burgoon and Dekker (2010), and Marx (forthcoming). 
The bottom line is that we have little empirical knowledge on the effect of labour market status on preferences for or against employment protection. In the remainder of the paper, we will analyse two hypotheses:

1. Compared to insiders, outsiders demand a lower level of employment protection

2. Compared to insiders, outsiders demand a higher level of unemployment benefits

Going beyond these straightforward hypotheses, we propose a theoretical extension of insideroutsider theory. In our view, insider-outsider theory neglects important heterogeneity within both segments and exaggerates mobility barriers between them. In reality, insiders do become unemployed and temporary workers as well as unemployed can find permanent jobs (Gash 2008). However, regarding actual prospects of upward (or downward) mobility, temporary workers are a heterogeneous group and the same is true for the unemployment risk of permanent workers (Rehm 2009). Besides individual factors a major factor explaining this heterogeneity should be occupational risk profiles (ibid.).

What are the consequences for support of employment protection? If, for instance, workers' occupations are characterized by favourable labour demand and supply conditions, neither category has to worry all that much about unemployment (and employment protection). We would expect the preferences for employment protection to be more polarized in occupational groups with a shortage of jobs. Here, temporary workers have relatively weak prospects of making an upward transition. Rather than anticipating future 'insiderness', they anticipate unemployment and their opposition to employment protection may even grow (following the 'mobility barrier hypothesis'). In any case, they currently do not benefit from employment protection and the occupational employment situation does not produce additional incentives to support it. The situation is reversed for the permanent workers. The more adverse the occupational employment situation, the stronger the support for employment protection. For many of these workers employment protection is the only thing standing between them and unemployment and is probably seen as the single most important piece of labour market regulation. Hence, we expect: 
3. Permanent workers facing high occupational unemployment exhibit stronger support for employment protection, whereas temporary workers' support is not affected or even lower.

\section{The French reform debate and the contrat de travail unique}

We analyse our hypothesis in the context of an on-going reform debate in France. The French labour market exemplifies a two-contract regime (DiPrete et al. 2006; Palier and Thelen 2010). It is characterized by strict regulation of dismissals for open-ended contracts (Venn 2009) and the frequent use of fixed-term contracts (contrat à durée determine or CDD). Although the share of fixed-term workers equals only $10 \%$ of the French workforce, more than $70 \%$ of new hirings are made through fixed-term contracts. Such contracts are often associated with unfavourable labour market outcomes, such as wage gaps and lack of occupational upward mobility (Blanchard and Landier 2002; Gash 2008). Particularly younger and low-skilled workers are affected. Regarding workers between 15 and 24 years, only 47.8\% have an open-ended contract in France, compared to an average of $75.9 \%$ in the OECD (Cahuc and Kramarz 2004).

In combination with persistently high unemployment rates, growing labour market dualism has produced more than three decades of reform debates about employment protection. Arguments and policy changes have generally oscillated between fostering general flexibility by deregulating dismissal regulation, increasing dualism by selectively deregulating fixed-term contracts, or overcoming dualism by making it more costly to hire on fixed-term contracts (Marx 2012). Hence, employment protection has been a salient political issue for a long time. Cases in point are the employment protection reforms proposed in 2005 by the conservative government. The contrat première embauche (for young workers) and the contrat nouvelle embauche (for workers in very small firms) were intended to allow firms laying off workers during the first two years of employment without the usual restrictions. After this period, the contract would be converted into a permanent one. Following major street protests, implementation of both types of contracts eventually failed. The general idea of eliminating the "sharp contrasts" (Blanchard and Tirole 2003: 39) between temporary and permanent contracts remained however on the political agenda (Cahuc and Kramarz 2004; LIEPP/OECD 2013; Amable 2013). Creating a single employment contract (or contrat de travail unique), which would replace the existing two types 
of contracts but would be more flexible than permanent contracts in the status quo, was part of Nicolas Sarkozy’s program for the presidential campaign in 2007, and François Bayrou's program for the 2012 contest.

We make use of the visible reform debate on the single employment contract in France to analyse preferences for employment protection. Our general hypothesis can be straightforwardly translated into the French context: Compared to insiders (permanent workers), outsiders (fixedterm contract workers and the unemployed) should be in favour of the single employment contract. This is simply because the new contract would make it easier for them to obtain a permanent contract in the future. Permanent workers should oppose the idea since they would have to compromise on their current level of protection.

\section{Data}

We use a survey of 2014 registered voters collected after the second round of the 2012 French presidential election. ${ }^{1}$ To assess the support for employment protection, we make use of a question on the single labour contract that reads as follows: "Would you be in favour of or against the establishment of a single employment contract replacing the fixed term contracts and permanent employment contract? It would become easier to fire someone with this type of single employment contract than to fire someone with a permanent employment contract but the severance payments would increase with seniority.” The precise wording of the question avoids any misunderstanding regarding the implications of the single labour contract on employment protection. We thus use the answers to this question to assess the support for employment protection (dummy), assuming that individuals that are not in favour of the single labour contract do instead value employment protection.

Our key explanatory variable is individuals' employment status. Corresponding to our hypotheses, we distinguish permanent and temporary contracts. Among the former we make an additional distinction between full time and part time. It is often argued that only permanent full time workers can be considered real labour market insiders. We further distinguish the unemployed, the civil servants, and the inactive. Missing values are included into the regressions

\footnotetext{
${ }^{1}$ This survey has been conducted in the framework of the project 'The political economy of the 2012 election' (PI Nicolas Sauger), funded by the Mairie de Paris (research programme Emergences) and Sciences Po.
} 
to avoid potential bias through a reduced sample (but not shown in the regression output). The distribution of attitudes towards the single employment contract by labour market status is shown in Table 1.

Table 1. Distribution of answers on the single labour contract by employment status

\begin{tabular}{lccccc}
\hline employment status & in favour & strongly in favour & against & strongly against & total \\
\hline permanent full time & 6.61 & 28.02 & 37.36 & 28.02 & 100 \\
permanent part time & 10.26 & 29.49 & 34.62 & 25.64 & 100 \\
fixed term & 6.74 & 25.84 & 38.20 & 29.21 & 100 \\
self employed & 20.29 & 33.33 & 28.99 & 17.39 & 100 \\
unemployed & 13.28 & 32.03 & 25.78 & 28.91 & 100 \\
inactive & 11.19 & 41.01 & 26.23 & 21.57 & 100 \\
civil servant & 3.61 & 27.11 & 43.98 & 25.30 & 100 \\
missing value & 10.81 & 32.43 & 35.14 & 21.62 & 100 \\
\hline total & 9.56 & 34.04 & 31.93 & 24.47 & 100 \\
\hline
\end{tabular}

We also investigate whether the insider/outsider divides helps explain the support for unemployment insurance. The survey question we use reads as follows: "Concerning the spending on policies on unemployment insurance and job training for the unemployed, should there be much more, somewhat more, the same, somewhat less or much less spending than now?”. The question is clearly in relative terms. We thus interpret individuals answering there should be (much) more spending on unemployment insurance as people showing a strong support for unemployment benefits given the actual insurance level (dummy). The distribution of attitudes towards unemployment insurance by labour market status is shown in Table 2.

Table 2. Distribution of answers on level of unemployment insurance by employment status

\begin{tabular}{lcccccc}
\hline employment status & much more & more & the same & less & much less & total \\
\hline permanent full time & 14.41 & 30.16 & 34.81 & 15.96 & 4.66 & 100 \\
permanent part time & 14.29 & 30.95 & 36.90 & 13.10 & 4.76 & 100 \\
fixed term & 14.29 & 44.90 & 29.59 & 11.22 & 0.00 & 100 \\
self employed & 8.00 & 30.67 & 28.00 & 26.67 & 6.67 & 100 \\
unemployed & 28.57 & 37.86 & 23.57 & 7.86 & 2.14 & 100 \\
inactive & 14.17 & 35.66 & 34.74 & 12.34 & 3.09 & 100 \\
civil servant & 18.54 & 33.15 & 34.83 & 11.80 & 1.69 & 100 \\
missing value & 20.51 & 25.64 & 38.46 & 10.26 & 5.13 & 100 \\
\hline total & 15.57 & 34.18 & 33.61 & 13.30 & 3.35 & 100 \\
\hline
\end{tabular}

In all regressions, we control for age, gender, union membership, education, and income (adjusted to household size). Additional controls include self-placement on the left-right scale 
(dummy for left-wing ideology), occupation dummies, self-reported household income dynamics in the past 12 months, and subjective employability (whether respondents consider it difficult to find another job within 12 months in case of job loss).

\section{Results}

Table 3 presents results of regressions of employment protection preferences on labour market status and a range of control variables. The findings do not support the hypothesis derived from the insider-outsider literature: there is no significant difference between workers with permanent and fixed-term contracts. This is robust to adding several controls (models 1-3). However we do find a clear divide between wage-earners and the groups of self-employed and unemployed respondents. Both groups are significantly more in favour of a more flexible single employment contract. This is not surprising for the self-employed who often employ dependent workers themselves. The strong and significant effect for the unemployed indicates that the insideroutsider argument is relevant for this group. Interestingly, the unemployed and the self-employed seem to converge on the issue of employment protection. Finally, the negative effect for the inactive may be caused by pensioners who do not directly benefit (anymore) from employment protection. This interpretation also explains the negative effect of being older than age 54 . Among the remaining control variables, only skill level is significant. As could be expected, support for employment protection decreases with skill level and increases with left wing ideology. Somewhat surprisingly, union membership is not a significant predictor of employment protection preferences. 
Table 3. Preferences for employment protection (binary logit)

\begin{tabular}{|c|c|c|c|}
\hline & \multicolumn{3}{|c|}{ employment protection } \\
\hline & model 1 & model 2 & model 3 \\
\hline \multicolumn{4}{|l|}{ permanent full time - REF } \\
\hline \multirow[t]{2}{*}{ permanent part time } & -.249 & -.150 & -.133 \\
\hline & $(.249)$ & $(.255)$ & $(.257)$ \\
\hline \multirow[t]{2}{*}{ fixed term } & -.082 & -.088 & -.106 \\
\hline & $(.236)$ & $(.241)$ & $(.243)$ \\
\hline \multirow[t]{2}{*}{ self employed } & $-.734 * * *$ & $-.598 * *$ & $-.569 *$ \\
\hline & $(.257)$ & $(.298)$ & $(.299)$ \\
\hline \multirow[t]{2}{*}{ unemployed } & $-.569 * * *$ & $-.570 * * *$ & $-.641 * * *$ \\
\hline & $(.201)$ & $(.203)$ & $(.205)$ \\
\hline \multirow[t]{2}{*}{ inactive } & $-.430 * * *$ & $-.458 * *$ & $-.437 * *$ \\
\hline & $(.147)$ & $(.178)$ & $(.180)$ \\
\hline \multirow[t]{2}{*}{ civil servant } & .126 & .102 & .113 \\
\hline & $(.191)$ & $(.207)$ & $(.208)$ \\
\hline young (18-34) -REF & & & . \\
\hline \multirow[t]{2}{*}{ middle age (35-54) } & -.100 & -.080 & -.045 \\
\hline & $(.138)$ & $(.141)$ & $(.142)$ \\
\hline \multirow[t]{2}{*}{ old $(>54)$} & $-.763 * * *$ & $-.717 * * *$ & $-.726 * * *$ \\
\hline & $(.150)$ & $(.174)$ & $(.176)$ \\
\hline \multirow[t]{2}{*}{ female } & -.137 & -.063 & -.039 \\
\hline & $(.096)$ & (.109) & (.109) \\
\hline \multirow[t]{2}{*}{ union member } & $.300 *$ & .252 & .174 \\
\hline & $(.181)$ & $(.183)$ & $(.185)$ \\
\hline \multirow{3}{*}{$\begin{array}{l}\text { education }<=\text { bac }-R E F \\
\text { undergraduate }\end{array}$} & & . & . \\
\hline & $.282 * *$ & $.254 *$ & $.240^{*}$ \\
\hline & $(.130)$ & $(.144)$ & $(.145)$ \\
\hline \multirow[t]{2}{*}{ graduate } & $-.491 * * *$ & $-.374 *$ & $-.428 * *$ \\
\hline & $(.166)$ & $(.206)$ & $(.209)$ \\
\hline \multicolumn{4}{|l|}{ low income -REF } \\
\hline \multirow[t]{2}{*}{ middle income } & .049 & .059 & .080 \\
\hline & $(.108)$ & $(.111)$ & $(.112)$ \\
\hline \multirow[t]{2}{*}{ high income } & $-.363 *$ & -.317 & -.236 \\
\hline & $(.214)$ & $(.221)$ & $(.223)$ \\
\hline \multirow[t]{2}{*}{ left ideology } & & & $.525^{* * *}$ \\
\hline & & & $(.098)$ \\
\hline occupation dummies & & yes & yes \\
\hline Number of Obs. & 2014 & 2014 & 2014 \\
\hline Pseudo R-Sq. & .063 & .072 & .082 \\
\hline Log likelihood & -1307.5 & -1295.1 & -1280.7 \\
\hline Chi 2 & 176.54 & 201.30 & 230.10 \\
\hline
\end{tabular}


In Table 4 we present results for the dependent variable measuring preferences for unemployment benefits. Again, the unemployed show a highly significant coefficient, as expected with a positive sign (indicating stronger support for unemployment benefits). Contrary to what we found for employment protection preferences, temporary workers show a similar preference pattern this time. Albeit somewhat weaker, their coefficient is significant and positive across model specifications. Besides labour market status, low income and left wing ideology are strong predictors of preferences for unemployment benefits.

The results suggest that insider-outsider differences have stronger implications for welfare state demand than for attitudes towards labour market regulation, at least regarding temporary workers. This is plausible, since temporary employment has been shown to be a strong predictor of subjective and factual unemployment risk (Burgoon and Dekker 2010; Gash 2008). Nonetheless, it may be that the dummy for temporary employment picks up other factors explaining preferences for unemployment benefits. This is plausible since employment risks, including temporary employment, are clustered in certain occupations (Rehm 2009; 2011) and these may differ by additional explanatory variables. To account for this, we first add two subjective measures of social risks: whether it would be difficult for respondents to find another job within 12 months if they would lose their present job (dummy) and whether their household income decreased in the past 12 months (dummy). Both questions differ from short term unemployment risk which is arguably underlying the positive effect of temporary employment. The first variable captures employability, i.e. re-employment chances in case of job loss, which is a function of individuals' human capital (specificity) and occupational patterns of labour demand and supply. The second variable is concerned with (the experience of) negative income dynamics. Both variables have a significant effect in the expected direction, but they do not explain away the positive effect of temporary employment (model 2). In a next step, we include dummies for different occupational groups to account for any unobservable and observable heterogeneity on this level (model 3). Although this slightly diminishes the effect of temporary contracts, it remains significant. We hence conclude that temporary employment has an independent effect on preferences for unemployment benefits. 
Table 4. Preferences for unemployment benefits (binary logit)

\begin{tabular}{|c|c|c|c|}
\hline & \multicolumn{3}{|c|}{ unemployment benefits } \\
\hline & model 1 & model 2 & model 3 \\
\hline permanent full time -REF & . & . & \\
\hline \multirow[t]{2}{*}{ permanent part time } & -.078 & -.102 & -.111 \\
\hline & $(.243)$ & $(.245)$ & $(.252)$ \\
\hline \multirow[t]{2}{*}{ fixed term } & $.542 * *$ & $.514 * *$ & $.414^{*}$ \\
\hline & $(.232)$ & $(.234)$ & $(.241)$ \\
\hline \multirow[t]{2}{*}{ self employed } & -.293 & -.283 & -.052 \\
\hline & $(.257)$ & $(.263)$ & $(.300)$ \\
\hline \multirow[t]{2}{*}{ unemployed } & $.782 * * *$ & $.949 * * *$ & $.872 * * *$ \\
\hline & $(.205)$ & $(.224)$ & $(.230)$ \\
\hline \multirow[t]{2}{*}{ inactive } & .046 & $.295^{*}$ & .217 \\
\hline & $(.145)$ & $(.171)$ & $(.200)$ \\
\hline \multirow[t]{2}{*}{ civil servant } & .239 & .272 & .127 \\
\hline & $(.182)$ & $(.184)$ & $(.202)$ \\
\hline \multicolumn{4}{|l|}{ young (18-34) -REF } \\
\hline \multirow[t]{2}{*}{ middle age (35-54) } & .069 & .047 & .078 \\
\hline & $(.136)$ & $(.137)$ & $(.141)$ \\
\hline \multirow[t]{2}{*}{ old (>54) } & .146 & .106 & .167 \\
\hline & $(.148)$ & $(.149)$ & $(.175)$ \\
\hline \multirow[t]{2}{*}{ female } & .101 & .086 & .013 \\
\hline & $(.094)$ & $(.094)$ & $(.108)$ \\
\hline \multirow[t]{2}{*}{ union member } & $.307^{*}$ & .266 & .116 \\
\hline & $(.173)$ & $(.174)$ & $(.179)$ \\
\hline education $<=$ bac $-R E F$ & . & . & . \\
\hline \multirow[t]{2}{*}{ undergraduate } & .011 & .033 & -.108 \\
\hline & $(.126)$ & $(.127)$ & $(.144)$ \\
\hline \multirow[t]{2}{*}{ graduate } & .073 & .065 & .000 \\
\hline & $(.161)$ & $(.162)$ & $(.206)$ \\
\hline low income -REF & . & . & . \\
\hline \multirow[t]{2}{*}{ middle income } & $-.373 * * *$ & $-.340 * * *$ & $-.334 * * *$ \\
\hline & $(.105)$ & $(.106)$ & $(.111)$ \\
\hline \multirow{2}{*}{ high income } & $-1.035 * * *$ & $-.967 * * *$ & $-.897 * * *$ \\
\hline & $(.216)$ & $(.218)$ & $(.228)$ \\
\hline \multirow[t]{2}{*}{ hh income decreased past 12 months } & & $.258^{* *}$ & $.241 * *$ \\
\hline & & $(.102)$ & $(.105)$ \\
\hline \multirow[t]{2}{*}{ difficult to find another job } & & $.413^{* * *}$ & $.361 * *$ \\
\hline & & $(.137)$ & $(.141)$ \\
\hline \multirow[t]{2}{*}{ left ideology } & & & $.628 * * *$ \\
\hline & & & $(.096)$ \\
\hline occupation dummies & & & yes \\
\hline Number of Obs. & 2014 & 2014 & 2014 \\
\hline Pseudo R-Sq. & .024 & .030 & .055 \\
\hline Log likelihood & -1360.3 & -1352.4 & -1317.0 \\
\hline Chi 2 & 67.94 & 83.67 & 154.55 \\
\hline
\end{tabular}

Note: Standard errors in parentheses. ${ }^{*} \mathrm{p}<0.10,{ }^{* *} \mathrm{p}<0.05$, ${ }^{* * *} \mathrm{p}<0.01$ 


\section{Occupational risk profiles}

In the previous section, we showed that permanent and temporary workers do not differ in their support for employment protection. This finding may disguise considerable heterogeneity within both segments. We argue that occupational risk profiles are a relevant source of heterogeneity. According to our argument, permanent workers in high-risk occupation should exhibit stronger support for employment protection than permanent workers in low-risk occupations. Temporary workers in high-risk occupations, on the other hand, should exhibit the same or even lower support for employment protection than temporary workers in low-risk occupations.

We analyse this assertion by including a multiplicative interaction term of employment status and occupational unemployment rate (OUER). The OUER was calculated as in Rehm (2009) based on the French labour force survey (Enquete emploi 2011). ${ }^{2}$ Unfortunately, the size of our data set is not very suitable to explore interaction effects. Excluding the inactive, civil servants and self-employed (who are, for different reasons, not affected by the risk of unemployment) reduces our sample size to 781. Among these, we only distinguish permanent workers, temporary workers and the unemployed. The absolute number of observed temporary workers is only about 100. This means that we have relatively few observations for any given level of OUER producing large confidence intervals. As a consequence of these data limitations, we cannot test our third hypothesis rigorously, but restrict ourselves to cautiously assessing whether the tendency in the data is in line with our expectations.

Figure 1 plots the average probabilities of permanent and temporary workers as well as of the unemployed to support employment protection over the range of observed OUER values (based on the interaction term in Table A3 in the appendix). To begin with, the difference between permanent and temporary workers is not significant at any level of OUER. However, we do observe the expected tendency of permanent workers to show stronger support for employment protection in high-risk occupations. The gap in support between the highest and the smallest OUER is about eleven percentage points. Almost the exact opposite is true for temporary workers. In high-risk occupations, they tend to converge to the (low) level of support observed among the unemployed. Again, we have to treat this second finding with caution, since it is

\footnotetext{
${ }^{2}$ We are grateful to Baptiste Françon for sharing this data with us. We checked the accuracy of the data by using occupation to predict individuals' transitions into unemployment with data from Enquete emploi 2011. The results (obtainable upon request) validate the occupational unemployment rates we use in this article.
} 
based on a rather small number of observations. The unemployed generally seem to be unaffected by occupational unemployment rates, as their level of support hardly differs.

Figure 1. Average probabilities to support employment protection over different levels of occupational unemployment rates

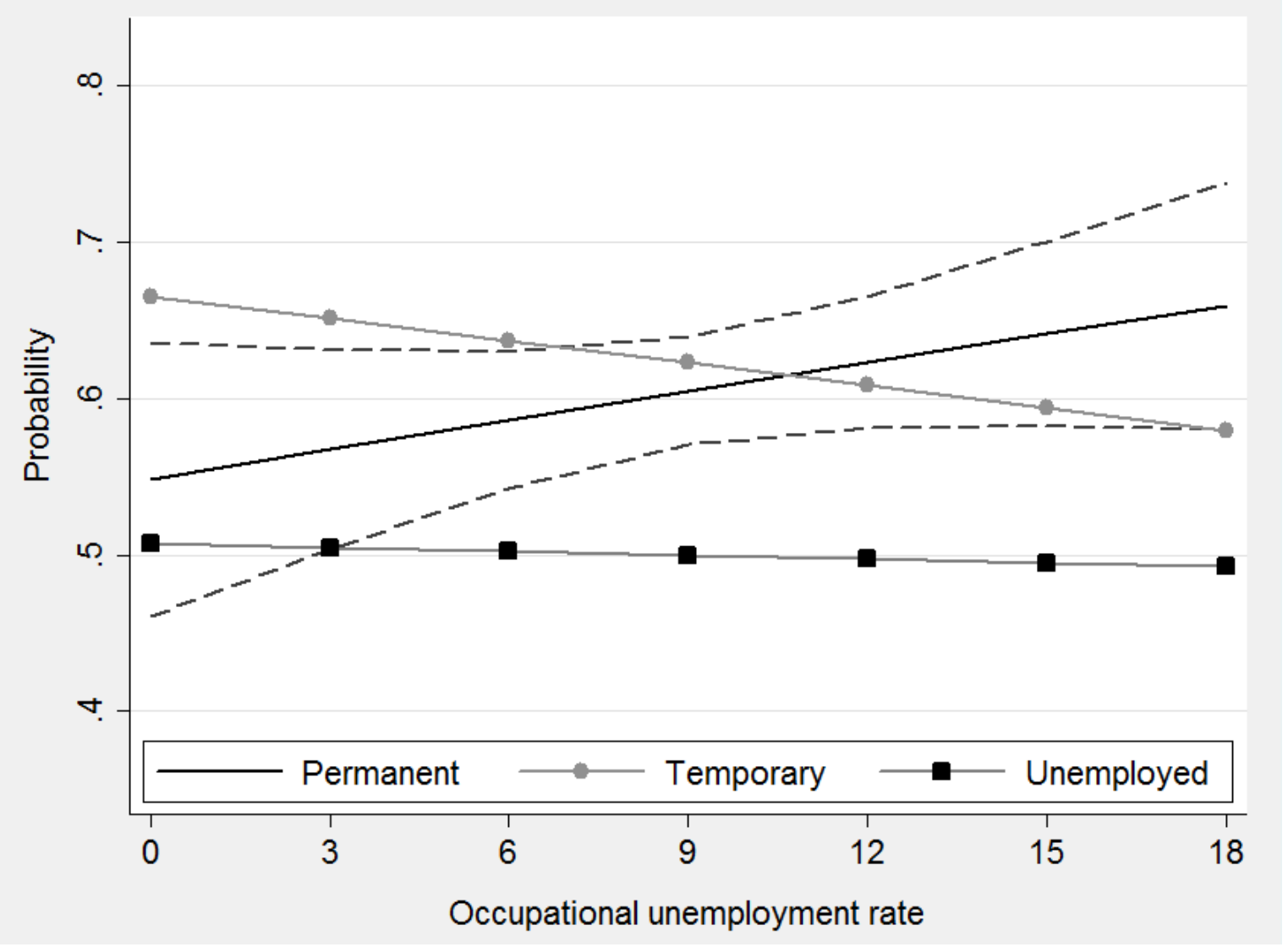

Note: average probabilities based on Table A3 in the appendix. Dotted lines represent 90 per cent confidence interval for permanent workers. Unemployed assigned to occupation of last job.

What can we conclude from these observations? The analysis reveals that permanent workers do not hold uniform preferences for or against employment protection. Support is higher if the employment situation is bad. Moreover, the data suggests that this logic is different among temporary workers. Under the condition of high OUER the gap in the level of support is wider. Although data constraints do not allow for firmer conclusions, our results can be seen as a plausibility check for the theoretical assertion that insider-outsider divides in policy preferences are conditioned by the broader risk environment. 


\section{Conclusion}

In this paper, we have investigated a prominent claim of the insider-outsider literature, according to which there is a divide in the population regarding preferences for employment protection. On the one side, permanently employed insiders are expected to support strong protection against dismissals. On the other side, the unemployed and temporary workers are supposed to support deregulation to foster labour market mobility. Using data from the most recent presidential election in France, a country which has been in the focus of insider-outsider literature, we could only confirm the argument for the unemployed. Temporary workers do not differ significantly from permanent workers regarding preferences for employment protection. This has two likely causes. First, as has been frequently pointed out, temporary workers may be too heterogeneous in their prospects of upward mobility. Some may anticipate prospective permanent employment and therefore adopt 'insider preferences' early on. The complementary second likely reason why we do not observe a clear gap is heterogeneity among permanent workers. There may be a sizeable segment in the group of permanent workers with only lukewarm support for employment protection as a consequence of high employability and/or favourable economic environment in their industry. Other permanent workers may deem their unemployment risk as high and consider their personal prospects in the external labour market as poor and therefore strongly support protection of existing jobs. Both types of heterogeneity appear plausible based on the observed interaction of employment status and occupational unemployment rates. We think that incorporating broader conceptions of risk into theories on insiders' and outsiders' political preferences is a promising way to further the debate. While we have analysed an objective risk factor as a moderator of employment status, exploring different forms of subjective mobility prospects are interesting alternatives for future research.

Our results do show that temporary employment matters more when it comes to welfare state demand. It appears that unemployment risk and the need for decent protection are more salient implications of temporary workers than calculations of mobility prospect. Therefore, our results suggest that in a European context temporary employment should receive more attention in the burgeoning literature on the effects of employment risk on policy preferences. 


\section{References}

Amable, Bruno (2013). "Who wants the contrat de travail unique? Social support for labour market flexibilisation in France”, working paper No. 2013.08, Centre d'Economie de la Sorbonne.

Bentolila, Samuel, and Giuseppe Bertola (1990). "Firing costs and labour demand: How bad is Eurosclerosis?”, Review of Economic Studies, 57:3, 381--402.

Bentolila, Samuel, and Juan J. Dolado (1994). "Labour flexibility and wages: Lessons from Spain”, Economic Policy, 9:18, 53--99.

Bentolila, Samuel, Juan J. Dolado, and Juan F. Jimeno (2012). "Reforming and insider-outsider labor market: The Spanish experience”, IZA Journal of European Labor Studies, 1:4.

Blanchard, Olivier, and Augustin Landier (2002). “The perverse effects of partial labor market reform: Fixed duration contracts in France”, Economic Journal, 117:521, 357--385.

Blanchard, Olivier, and Jean Tirole (2003). “Contours of Employment Protection Reform”, working paper No. 03-35, MIT Department of Economics.

Boeri, Tito, Axel Borsch-Supan, and Guido Tabellini (2001). "Would you like to shrink the welfare state? A survey of European citizens”, Economic Policy, 16:32, 7--50.

Botero, Juan, Simeon Djankov, Rafael La Porta Florencio Lopez-de-Silanes, and Andrei Shleifer (2004). “The regulation of labor”, Quarterly Journal of Economics, 119:4, 1339--1382.

Burgoon, Brian, and Fabian Dekker (2010). "Flexible employment, economic insecurity and social policy preferences in Europe”, Journal of European Social Policy, 20:2, 126--141.

Cahuc, Pierre, and Francis Kramarz (2004). “De la précarité à la mobilité : vers une sécurité sociale professionnelle”, La Documentation Française, coll. Rapports officiels.

Cusack, Thomas, Torben Iversen, and Philipp Rehm (2006). "Risks at work: The demand and supply sides of government redistribution”, Oxford Review of Economic Policy, 22:3, 365-389.

Davidsson, Johan Bo, and Patrick Emmenegger (2013). "Defending the organisation, not the members: Unions and the reform of job security legislation in Western Europe”, European Journal of Political Research, 52:3, 339--363.

DiPrete, Thomas A., Dominique Goux, Eric Maurin, and Amelie Quesnel-Vallee (2006). “Work and pay in flexible and regulated labor markets: A generalized perspective on institutional 
evolution and inequality trends in Europe and the U.S.”, Research in Social Stratification and Mobility, 24:3, 311--333.

Dolado, Juan J., Carlos Garcia-Serano, and Juan F. Jimeno (2002). "Drawing lessons from the boom of temporary jobs in Spain”, Economic Journal, 112:480, 270--295.

Emmenegger, Patrick (2009). "Barriers to entry: Insider/outsider politics and the political determinants of job security regulations”, Journal of European Social Policy, 19:2, 131--146.

Gash, Vanessa (2008). "Bridge or trap? Temporary workers transitions to unemployment and to the standard employment contract”, European Sociological Review, 24:5, 651-668.

Guillaud, Elvire (2013). "Preferences for redistribution: an empirical analysis over 33 countries", Journal of Economic Inequality, 11:1, 57--78.

Guillaud, Elvire, and Nicolas Sauger (2013). "Redistribution, Tax Policy, and the Vote: The 2012 French Presidential Election”, Parliamentary Affairs, 66:1, 87--105.

Hacker, Jacob S., Philipp Rehm, and Mark Schlesinger (2013). "The Insecure American: Economic Experiences, Financial Worries, and Policy Attitudes”, Perspectives on Politics 11:1, 23--49.

Häusermann, Silja, and Hanna Schwander (2012). "Varieties of dualization? Labor market segmentation and insider-outsider divides across regimes” In Patrick Emmenegger, Silja Häusermann, Bruno Palier and Martin Seeleib-Kaiser (Eds.), The age of dualization: The changing face of inequality in deindustrializing societies (pp. 27--51). Oxford; New York: Oxford University Press.

Iversen, Torben, and David Soskice (2001). “An asset theory of social policy preferences”, American Political Science Review, 95:4, 875--893.

Lepage-Saucier, Nicolas, Juliette Schleich, and Etienne Wasmer (2013). "Moving towards a single labour contract: pros, cons and mixed feelings”, working paper No. 1026, LIEPP/OECD Economics Department.

Lindbeck, Assar, and Dennis J. Snower (1988). "Cooperation, harassment, and involuntary unemployment: An insider-outsider approach,” American Economic Review, 78:1, 167--189.

Lindbeck, Assar, and Dennis J. Snower (2001). “Insiders versus outsiders”, Journal of Economic Perspectives, 15:1, 165--188.

Marx, Paul (2012). "Labour market dualisation in France. Assessing different explanatory approaches”, European Societies, 14:5, 704--726. 
Marx, Paul (forthcoming). "Labour market risks and political preferences: The case of temporary employment”, European Journal of Political Research.

Palier, Bruno, and Kathleen Thelen (2010). “Institutionalizing dualism: Complementarities and change in France and Germany”, Politics \& Society, 38:1, 119--148.

Rehm, Philipp (2009). “Risks and redistribution: An individual-level analysis”, Comparative Political Studies, 42:7, 855--881.

Rehm, Philipp (2011). “Social policy by popular demand”, World Politics, 63:2, 271--299.

Rueda, David (2005). "Insider-outsider politics in industrialized democracies: The challenge to social democratic parties”, American Political Science Review, 99:1, 61--74.

Rueda, David (2007). Social democracy inside out: Partisanship and labor market policy in industrialized democracies. Oxford: Oxford University Press.

Saint-Paul, Gilles (1996). "Exploring the political economy of labour market institutions", Economic Policy, 11:23, 265--300.

Saint-Paul, Gilles (2000). The political economy of labour market institutions. Oxford: Oxford University Press.

Venn, Danielle (2009). Legislation, collective bargaining and enforcement: Updating the OECD employment protection indicators, OECD Social, Employment and Migration Working Papers 2009; Nr. 89. 


\section{Appendix}

Table A1. Summary statistics

\begin{tabular}{|c|c|c|c|}
\hline & $\mathrm{n}$ & freq (\%) & $\mathrm{N}$ \\
\hline Support for employment protection & 991 & 49,21 & 2014 \\
\hline Support for unemployment benefits & 965 & 47,91 & 2014 \\
\hline \multicolumn{4}{|l|}{ Detailed employment status: last 7 days } \\
\hline permanent full time & 462 & 22,94 & 2014 \\
\hline permanent part time & 85 & 4,22 & 2014 \\
\hline fixed term & 99 & 4,92 & 2014 \\
\hline self employed & 78 & 3,87 & 2014 \\
\hline unemployed & 142 & 7,05 & 2014 \\
\hline inactive & 926 & 45,98 & 2014 \\
\hline civil servant & 183 & 9,09 & 2014 \\
\hline missing values & 39 & 1,94 & 2014 \\
\hline \multicolumn{4}{|l|}{ Age } \\
\hline young (18-34) & 370 & 18,44 & 2014 \\
\hline middle-age (35-54) & 711 & 35,44 & 2014 \\
\hline old $(>54)$ & 925 & 46,11 & 2014 \\
\hline missing values & 8 & 0,40 & 2014 \\
\hline Female & 1110 & 55,11 & 2014 \\
\hline Union member & 160 & 7,94 & 2014 \\
\hline \multicolumn{4}{|l|}{ University degree } \\
\hline baccalaureate or less & 1395 & 69,27 & 2014 \\
\hline undergraduate (L) & 376 & 18,67 & 2014 \\
\hline graduate (M-D) & 228 & 11,32 & 2014 \\
\hline missing values & 15 & 0,74 & 2014 \\
\hline \multicolumn{4}{|l|}{ Income (adjusted) } \\
\hline low-income & 762 & 37,84 & 2014 \\
\hline middle-income & 957 & 47,52 & 2014 \\
\hline high-income & 139 & 6,90 & 2014 \\
\hline missing values & 156 & 7,75 & 2014 \\
\hline Negative past income mobility (12 months) & 605 & 30,04 & 2014 \\
\hline Difficult to find another job (> 12 months) & 526 & 26,12 & 2014 \\
\hline \multicolumn{4}{|l|}{ Occupation } \\
\hline skilled agricultural worker & 32 & 1,59 & 2014 \\
\hline craftmen & 55 & 2,73 & 2014 \\
\hline shopkeepers & 40 & 1,99 & 2014 \\
\hline $\mathrm{CEO}$ & 11 & 0,55 & 2014 \\
\hline liberal professions & 17 & 0,84 & 2014 \\
\hline managers -public sector & 138 & 6,85 & 2014 \\
\hline managers -private firm & 120 & 5,96 & 2014 \\
\hline associate professionals -public sector & 184 & 9,14 & 2014 \\
\hline associate professionals -private firms & 87 & 4,32 & 2014 \\
\hline technicians & 66 & 3,28 & 2014 \\
\hline foremen & 50 & 2,48 & 2014 \\
\hline service workers -public sector & 219 & 10,87 & 2014 \\
\hline service workers -private firms & 138 & 6,85 & 2014 \\
\hline sales workers & 80 & 3,97 & 2014 \\
\hline
\end{tabular}


personal workers

plant and machine operators

elementary occupations

agricultural workers

missing values

Left ideology
114

238

150

15

260

866
5,66

11,82

7,45

0,74

12,91

43,00
2014

2014

2014

2014

2014

2014

Source: 2012 French election survey; Enquete Emploi 2011

Table A2. Occupational unemployment rate

\begin{tabular}{lc}
\hline Occupation & Unemployment rate \\
\hline skilled agricultural worker & 0,27 \\
craftmen & 3,43 \\
shopkeepers & 5,09 \\
CEO & 1,81 \\
liberal professions & 1,73 \\
managers -public sector & 3,08 \\
managers -private firm & 4,29 \\
associate professionals -public sector & 3,78 \\
associate professionals -private firms & 7,57 \\
technicians & 4,19 \\
foremen & 4,43 \\
service workers -public sector & 7,18 \\
service workers -private firms & 8,67 \\
sales workers & 15,14 \\
personal workers & 10,66 \\
plant and machine operators & 9,46 \\
elementary occupations & 18,88 \\
agricultural workers & 17,60 \\
\hline
\end{tabular}

Source: Enquete Emploi 2011 
Table A3. Preferences for employment protection (binary logit)

\begin{tabular}{|c|c|}
\hline & $\begin{array}{c}\text { employment protection } \\
\text { model } 1\end{array}$ \\
\hline \multicolumn{2}{|l|}{ unemployed -REF } \\
\hline permanent & $\begin{array}{c}.176 \\
(.462)\end{array}$ \\
\hline fixed term & $\begin{array}{c}.698 \\
(.631)\end{array}$ \\
\hline OUER & $\begin{array}{l}-.003 \\
(.038)\end{array}$ \\
\hline \multirow{2}{*}{$\begin{array}{l}\text { unemployed * OUER -REF } \\
\text { permanent * OUER }\end{array}$} & \\
\hline & $\begin{array}{c}.031 \\
(.043)\end{array}$ \\
\hline fixed term * OUER & $\begin{array}{l}-.018 \\
(.056)\end{array}$ \\
\hline \multirow{2}{*}{$\begin{array}{l}\text { young }(18-34)-R E F \\
\text { middle age (35-54) }\end{array}$} & . \\
\hline & $\begin{array}{l}.056 \\
(.178)\end{array}$ \\
\hline old (>54) & $\begin{array}{l}-.763 * * * \\
(.254)\end{array}$ \\
\hline female & $\begin{array}{l}-.284^{*} \\
(.155)\end{array}$ \\
\hline union & $\begin{array}{l}.600 * * \\
(.298)\end{array}$ \\
\hline \multicolumn{2}{|l|}{ education $<=$ bac $-R E F$} \\
\hline undergraduate & $\begin{array}{l}.470 * * \\
(.202)\end{array}$ \\
\hline graduate & $\begin{array}{l}-.067 \\
(.290)\end{array}$ \\
\hline \multirow{2}{*}{$\begin{array}{l}\text { low income-REF } \\
\text { middle income }\end{array}$} & . \\
\hline & $\begin{array}{l}.182 \\
(.175)\end{array}$ \\
\hline high income & $\begin{array}{c}-.858^{* *} \\
(.412)\end{array}$ \\
\hline public sector & $\begin{array}{c}.178 \\
(.208) \\
\end{array}$ \\
\hline Number of Obs. & 781 \\
\hline Pseudo R-Sq. & .053 \\
\hline Log likelihood & -501.3 \\
\hline Chi 2 & 56.54 \\
\hline
\end{tabular}

Note: Standard errors in parentheses.

${ }^{*} \mathrm{p}<0.10,{ }^{* *} \mathrm{p}<0.05,{ }^{* * *} \mathrm{p}<0.01$ 